\title{
O DIREITO À SAÚDE NAS CORTES SUPERIORES
}

The right to health in the Brazilian superior courts

${ }^{1}$ Universidade do Vale do Itajaí. Brusque/SC, Brasil.

Correspondência: cleniojschulze@yahoo.com.br

Recebido em: 14/05/2018. 


\section{Introdução}

O “Tema em Debate” desta edição da Revista de Direito Sanitário trata do "Direito à Saúde nas Cortes Superiores".

São três artigos, em que são abordadas decisões judiciais relacionadas a importantes questões da teoria do direito e da vida em sociedade. O primeiro trata dos conflitos morais enfrentados pelos magistrados federais. $\mathrm{O}$ segundo aborda a judicialização da saúde suplementar. E o último investiga decisões indenizatórias do Superior Tribunal de Justiça em danos obstétricos.

\section{Os conflitos morais enfrentados pelos juízes em demandas de saúde: o caso dos tribunais federais brasileiros}

O artigo de José Carlos Zebulum refere-se a tema de grande relevância para o constitucionalismo do século XXI: o impacto das questões morais nas decisões judiciais.

A avaliação é recheada com o pensamento de renomados filósofos do direito, tais como Ronald Dworkin e Richard Posner. Além disso, enfatiza-se a argumentação jurídica, a partir da proposta teórica de Manuel Atienza.

Com base nas aludidas premissas teóricas, o articulista pesquisou a jurisprudência dos cinco tribunais regionais federais brasileiros, encontrando o seguinte diagnóstico: (a) admissibilidade de fornecimento de tecnologias em saúde não registradas na Agência Nacional de Vigilância Sanitária (Anvisa); (b) deve haver cuidado na decisão judicial que envolve discussão sobre pedido para furar a fila de espera em internação hospitalar; e (c) há decisões judiciais que desconsideram a legislação vigente e autorizam tratamentos no exterior com base em argumentos morais.

\section{Judicialização em planos de saúde coletivos no Tribunal de Justiça de São Paulo em 2013 e 2014}

Neste artigo, Daniela Batalha Trettel, Juliana Ferreira Kozan e Mario César Scheffer analisam os efeitos da regulação da Agência Nacional de Saúde Suplementar (ANS) na relação contratual entre consumidores e operadoras de planos de saúde, a partir da posição do Tribunal de Justiça de São Paulo (TJSP).

A principal conclusão no texto reside na discrepância entre a posição do TJSP e a posição da agência reguladora, principalmente nas questões envolvendo "exclusão de coberturas, manutenção do aposentado no contrato coletivo e reajuste de mensalidade de idosos, por mudança de faixa etária e por aumento de sinistralidade".

A partir da acurada avaliação de 4.059 processos judiciais, os autores afirmam que: (a) há altíssima taxa de sucesso nas ações judiciais; (b) não há 
incorporação contratual e regulatória das posições do TJSP; (c) é preciso atualizar o conteúdo dos contratos coletivos em saúde.

\section{Indenizações em obstetrícia: estudo das decisões do Superior Tribunal de Justiça do Brasil de 2004 a 2014}

Thaísa Mara Leal Cintra Rodrigues e Altacílio Aparecido Nunes pesquisaram as decisões do Superior Tribunal de Justiça (STJ) envolvendo ações indenizatórias decorrentes de problemas em procedimentos obstétricos.

Os danos praticados na mulher em razão do ato médico configuram temas de alto relevo, pois impactam não apenas a figura da gestante, mas também do nascituro, da família e da sociedade em geral.

A análise dos julgamentos permitiu concluir que os danos são mais comuns em parto normal e que é indispensável a ampliação de estudos e medidas para reduzir as ocorrências de danos e sequelas no momento puerperal.

\section{Considerações finais}

O direito à saúde ganhou nova dimensão em razão do alto número de processos judiciais em tramitação no Brasil. A leitura do relatório Justiça em Números de 2017, do Conselho Nacional de Justiça (CNJ), permite observar que há 1.346.931 demandas em tramitação sobre o tema ${ }^{1}$.

E os artigos acima mencionados apontam que a judicialização não indica, necessariamente, melhorias no cotidiano das pessoas. Vale dizer que, a despeito do acesso ao Judiciário, os cidadãos não estão, em linhas gerais, obtendo mais benefícios em suas vidas.

Isso demonstra que ainda existe um grande espaço para avanço na concretização do direito à saúde. E os tribunais pátrios já perceberam. Basta ver que o STJ alterou sua posição sobre a judicialização da saúde pública e suplementar. Uma medida nova é não autorizar, por exemplo, a concessão de medicamentos não registrados na Anvisa (Recurso Especial 1.657.156 - RJ, julgado em 25/04/2018).

De outro lado, ainda não há um entendimento definitivo por parte do Supremo Tribunal Federal - que possui a última palavra no Poder Judiciário brasileiro -, pois houve suspensão no julgamento dos Recursos Extraordinários 566471 e 657718.

Assim, é preciso qualificar o debate sobre a judicialização da saúde, de modo a permitir a construção de uma Teoria da Decisão Judicial mais adequada aos preceitos da Constituição do Brasil e, principalmente, compatíveis com o direito fundamental à saúde. 
É isso que se pretende para conferir maior segurança e saúde às pessoas, de modo a garantir mais qualidade de vida e benefícios à sociedade.

\section{Referências}

SCHULZE, Clenio Jair. A judicialização da saúde no século XXI. Porto Alegre: Verbo Jurídico, 2018.

Clenio Jair Schulze - Doutorando em Ciência Jurídica pela Universidade do Vale do Itajaí (Univali); mestre em Ciência Jurídica pela Univali. Juiz federal em Santa Catarina. Autor do livro Judicialização da saúde no século XXI e coautor do livro Direito à saúde - análise à luz da judicialização. Brusque/SC, Brasil.E-mail: cleniojschulze@yahoo.com.br 